\title{
Feminine hygiene practices among female patients and nurses in Lebanon
}

Elie Attieh¹, Samer Maalouf ${ }^{1}$, Dina Roumieh, Pamela Abdayem², Georges AbiTayeh and Assaad Kesrouani ${ }^{*}$

\begin{abstract}
Background: Inappropriate feminine hygiene practices are related to vulvovaginitis. We investigated the prevalence of personal hygiene habits among Lebanese women as well as their awareness of adequate practices.

Methods: Consists of a cross-sectional observational study. Female patients and nurses at Hotel-Dieu de France University Hospital in Beirut- Lebanon filled a questionnaire about their intimate hygiene habits and knowledge of proper practices.

Results: The study included 249 women. $21.3 \%$ of the 136 nurses and $38.9 \%$ of the 113 patients reported a history of vulvovaginitis. The majority of women took an intimate bath at least twice daily. $14 \%$ of nurses and $17 \%$ of patients douched.20. Seven percent of the nurses and $43.4 \%$ of the patients used wet wipes. $1.5 \%$ of nurses and $4.4 \%$ of patients used feminine deodorant sprays. There was a significant lack of awareness mainly among patients about suitable hygiene practices as well for their adverse effects.

Conclusion: Education provided by nurses, and other healthcare providers is essential to promote reproductive health among Lebanese women.
\end{abstract}

Keywords: Hygiene, Vaginal infections, Vaginal douching, Vaginitis

\section{Background}

Vulvovaginitis, a widespread disorder of the vagina accounts for approximately 10 million office visits to gynecologists every year in the United States (US) [1]. In a random digit dialing survey, 8 percent of Caucasian women and $18 \%$ of African-American women in the US reported an episode of vaginal symptoms in the previous year [2]. Symptoms include pruritus, erythema, pain, vulvar excoriations as well as changes in the color or odor or volume of vaginal discharge [3]. Studies indicated that each practice disrupting the normal vaginal ecosystem leads to the development of vulvovaginitis [4].

Perceptions about reproductive health issues differ significantly between countries, societies, and individuals. Socioeconomic status, race, religion and level of education influence women's perceptions and behaviors regarding their reproductive health. In particular, feminine hygiene practices vary among women with a high

\footnotetext{
* Correspondence: drkesrouani@gmail.com

'Obstetrics and Gynecology Department, Faculty of Medicine, Saint Joseph University, Hotel-Dieu de France Hospital, PO Box: 166830Adib Ishac Street, Achrafie, Beirut, Lebanon

Full list of author information is available at the end of the article
}

prevalence of erroneous behaviors that predispose them to vulvovaginitis.

While few studies about certain feminine hygiene practices, especially vaginal douching, have been conducted in the US and in countries such as Egypt and Turkey, information about intimate hygiene practices among Lebanese women is lacking. Hence, we conducted a cross-sectional study to determine the prevalence of several intimate hygiene habits and their level of knowledge in a population of Lebanese women including nurses and patients. Our aim is to assess the level of public awareness about this subject and the subsequent need for educational interventions to optimize reproductive health in Lebanon.

\section{Methods}

A cross-sectional observational study was conducted at Hotel-Dieu de France University Hospital in Beirut, Lebanon, between January and April 2014. The study population included all female registered nurses at the hospital as well as all the female patients admitted to the 
department of Obstetrics and Gynecology. There were no exclusion criteria except illiteracy.

Hotel-Dieu de France's ethical committee approved the study protocol. Investigators provided information about the study to all participants. Oral informed consent is mandatory for all participants before answering the questionnaire that includes a four-page questionnaire, available in French and Arabic languages. The Arabic translation is tested on a population of 10 medical residents and declared identical in meaning to the original French version. Participants were given privacy and time to complete the questionnaire without any disturbance or discomfort.

The questionnaire included three sections. The first section collected socio-demographic data as well as general medical history and reproductive history. The second section inquired about intimate hygiene habits, contraception and vulvovaginitis symptoms, while the third one evaluated women's awareness about adequate practices by means of yes or no questions. We assessed mainly the frequency of intimate wash, vaginal douching, use of wipes and deodorants, pubic hair removal and vulvovaginitis.

The collected data was analyzed using Statistical Package for Social Science software (SPSS, version 20).

\section{Results}

One hundred and forty-seven patients and 330 nurses were asked to complete the questionnaire between January and April 2014. One hundred and thirteen patients (76.8 \%) and 136 nurses (41.2\%) agreed to participate. The mean age of patients was 41.8 and of nurses was 32.4. The first population selected consists of nurses at
Hotel-Dieu de France Hospital, who are predominantly Christian (94.1\%) and reside in urban areas with half of them being married. The second population includes female patients admitted to the Obstetrics and Gynecology department at Hotel-Dieu de France Hospital who are predominantly married (92\%), mostly Christian (69 \%), housewives (54.9 \%) with a university education (59.3\%). Socio-demographic characteristics of the studied population are listed in Table 1.

Twenty-nine nurses $(21.3 \%)$ had a history of vaginitis and $5(17.2 \%)$ were treated more than once yearly, whereas 44 patients $(38.9 \%)$ had a history of vaginitis and $11(25 \%)$ had recurrent vaginitis. The most commonly reported symptoms of vulvovaginitis were pruritus ( $8.8 \%$ of the nurses and $9.7 \%$ of the patients) and burning sensation (3.7 \% of the nurses and $2.7 \%$ of the patients).

The majority of women took an intimate bath at least twice daily $(90.5 \%$ of the nurses versus $84.1 \%$ of the patients. Table 2 details various reasons for intimate bathing among nurses and patients.

Vaginal douching was common for $14 \%$ of nurses and $15 \%$ of patients. They used plain water (33\%), commercial solutions (22\%), bicarbonate-based solutions (22\%) and soap and water $(20 \%)$.

The two groups used a similar method to insert the liquid products inside the vagina (mostly sponges). Sixty-six percent of patients reported daily basis douching while $60 \%$ of nurses douched only once weekly. Twice daily intimate washing is more frequent among nurses. They undergo intimate washing more frequently before and after sports, after sexual intercourse, after defecation, after menstruation and in the case of

Table 1 Socio-demographic characteristics of the studied population

\begin{tabular}{|c|c|c|c|c|}
\hline Category & Sub-Category & Nurses $(n=136)$ & Patients $(n=113)$ & $p$ \\
\hline \multirow[t]{3}{*}{ Education } & Middle School & $0(0 \%)$ & $11(9.7 \%)$ & \multirow[t]{3}{*}{0.0001} \\
\hline & High School & $1(0.7 \%)$ & $28(24.8 \%)$ & \\
\hline & University & $135(99.3 \%)$ & 67 (59.3 \%) & \\
\hline \multirow[t]{4}{*}{ Profession } & Student & $1(0.7 \%)$ & $1(0.9 \%)$ & \multirow[t]{4}{*}{0.0001} \\
\hline & Employee & 131 (96.3 \%) & 43 (41.1 \%) & \\
\hline & Independent & $3(2.2 \%)$ & $6(5.3 \%)$ & \\
\hline & House wife & $0(0 \%)$ & $62(54.9 \%)$ & \\
\hline \multirow[t]{4}{*}{ Civil status } & Single & $52(38.2 \%)$ & 7 (6.2 \%) & \multirow[t]{4}{*}{0.0001} \\
\hline & In a relationship & $7(5.1 \%)$ & $0(0 \%)$ & \\
\hline & Married & $76(55.9 \%)$ & $104(92 \%)$ & \\
\hline & Divorced/Widowed & $1(0.7 \%)$ & $1(1.8 \%)$ & \\
\hline \multirow[t]{4}{*}{ Religion } & Christian & $128(94.1 \%)$ & 78 (69 \%) & \multirow[t]{4}{*}{0.001} \\
\hline & Muslim & $5(3.7 \%)$ & $21(18.6 \%)$ & \\
\hline & Druze & $1(0.7 \%)$ & $2(1.8 \%)$ & \\
\hline & Other & $2(1.5 \%)$ & $0(0 \%)$ & \\
\hline
\end{tabular}


Table 2 Reasons for intimate bathing among nurses and

\begin{tabular}{llll} 
patients & & & \\
\hline Reasons for intimate bathing & Nurses & Patients & p-value \\
\hline To feel fresh & $114(83.8 \%)$ & $97(85.8 \%)$ & 0.93 \\
Before sports & $24(17.6 \%)$ & $11(9.8 \%)$ & 0.0001 \\
After sports & $80(58.8 \%)$ & $26(23.2 \%)$ & 0.0001 \\
Before sexual intercourse & $66(48.5 \%)$ & $56(50 \%)$ & 0.00008 \\
After sexual intercourse & $78(57.4 \%)$ & $56(49.6 \%)$ & 0.000003 \\
After defecation & $66(48.5 \%)$ & $52(46.4 \%)$ & 0.000027 \\
After miction & $39(28.7 \%)$ & $45(39.8 \%)$ & 0.00048 \\
Before menstruation & $40(29.4 \%)$ & $38(33.6 \%)$ & 0.000003 \\
After menstruation & $94(69.1 \%)$ & $71(63.4 \%)$ & 0.000134 \\
To prevent infections & $84(61.8 \%)$ & $55(49.1 \%)$ & 0.0001 \\
To treat infections & $65(47.8 \%)$ & $19(16.8 \%)$ & 0.0001 \\
To get rid of vaginal discharge & $81(59.6 \%)$ & $31(27.4 \%)$ & 0.0001 \\
To get rid of vaginal odor & $86(63.2 \%)$ & $36(31.9 \%)$ & 0.0001 \\
Relief from itching & $75(55.1 \%)$ & $22(19.5 \%)$ & 0.0001 \\
\hline
\end{tabular}

infections, discharge, foul odors or pruritus. On the other hand, washing before intercourse, before menstruation and after urination are more common in the patient group.

The use of wet wipes for intimate cleaning was reported in $20.7 \%$ of the nurses and $43.4 \%$ of the patients. No significant difference was found between the two groups regarding the use of vaginal deodorant sprays (1.5\% of nurses versus $4.4 \%$ of patients,). As for other adequate hygiene practices, both patients and nurses seem to be aware of the utility of wearing cotton underwear and avoiding tight-fitting clothes to prevent trapping of sweat, bacterial and fungal multiplication and subsequent vaginitis. Moreover, $60.2 \%$ of the patients and $35.3 \%$ of nurses do not know that tampons should be changed at least twice a day regardless of the menstrual flow to decrease vaginal discharge and to prevent odors, as well as bacterial and fungal growth. The women in our study recognize signs of vaginal infections and are aware that white or yellow vaginal discharge can be normal.

Regular pubic hair removal was similar between the two populations $(78.7 \%$ of nurses versus $71.7 \%$ of patients,). $13.2 \%$ of the nurses and $17.7 \%$ of the patients reported subsequent irritation with the majority of the reactions resulting from the use of wax $(5.9 \%$ of nurses and $10.6 \%$ of patients) and shaving cream (9.6\% of nurses and $3.5 \%$ of patients).

The extent of knowledge of the two populations regarding reproductive health issues, particularly feminine hygiene practices is different regarding vaginal douche, deodorant spray and how to wipe after defecation and is fully detailed in Table 3.

\section{Discussion}

Vulvovaginitis is a common gynecologic condition. Many preventable causes of vaginitis are related to feminine hygiene practices, which vary considerably by race, age, religion and cultural origins.

The main findings of this study include describing several common feminine hygiene habits among Lebanese women and assessing the level of awareness about adequate hygiene practices.

The prevalence of vaginitis and recurrent vaginitis in this study is significantly lower among nurses, which emphasizes the role of education in the prevention of this condition.

Vaginal douching by a liquid solution in the vagina in the aim of cleanliness, odor control, or relief of vaginal itching and irritation is a common practice worldwide especially among African American and Muslim women [4]. The use of douching is similar between our two groups (14\% of nurses and $15.1 \%$ of patients) and is considerably less than the prevalence reported by Shaaban et al. in Egypt (73 \%), Erbil et al. (38.6 \%) and Ege et al. (61.5 \%) in Turkey [5-7]. This difference could be explained by the fact that the majority of the women in our study are Christians and do not douche for religious reasons as in other countries in the Middle-East. Thirty-seven percent of women reported douching in a study by Aral et al. in a nationally representative sample of 8450 women between the ages of 15 and 44 years reported that $37 \%$ of them used douching [8]. Another cross-sectional study by Cottrel et al. showed that $76 \%$ of 483 women in Florida douched, $43 \%$ douched once per month, and $36 \%$ were unaware they should not douche [9]. Our findings are different from US studies. This could be explained by the high prevalence of douching among African American women $(27.7 \%$ of African American women versus $9.1 \%$ of white women and $15 \%$ of Hispanic women) and among women who have multiple sexual partners $[10,11]$. Low socioeconomic status and lack of education are also associated with increased douching [12]. The high rate of college education among women may also explain the low percentage of douching. Half the nurses (52.2\%) know that douching may injure the vaginal mucosa and $63.2 \%$ state that douching should be performed per doctor's order, yet a third of them still mention indications for douching. On the other hand, a greater number of female patients responded "Do not know" to the questions about the indications for douching. Douching should be discouraged because it alters the vaginal flora and predisposes women to bacterial vaginosis, pelvic inflammatory disease, endometritis and sexually transmitted infections $[13,14]$. Ott et al. examined the association between the use of feminine hygiene products (wipes, sprays, douches and yeast creams) and sexually transmitted 
Table 3 Extent of knowledge regarding reproductive health issues in females patients and nurses

\begin{tabular}{|c|c|c|c|c|c|}
\hline & & Yes & No & Do not know & p-value \\
\hline \multirow{3}{*}{$\begin{array}{l}\text { Spray deodorant gets rid of vaginal odor } \\
\text { if used regularly }\end{array}$} & Nurses & $6.7 \%$ & $49.6 \%$ & $42.2 \%$ & \multirow[t]{3}{*}{0.696} \\
\hline & Patients & $4.4 \%$ & $46.0 \%$ & $46.9 \%$ & \\
\hline & Total & $5.6 \%$ & $48.0 \%$ & $44.4 \%$ & \\
\hline \multirow{3}{*}{$\begin{array}{l}\text { Spray deodorant can replace the use of } \\
\text { soap and water }\end{array}$} & Nurses & $0.7 \%$ & $80.9 \%$ & $17.6 \%$ & \multirow[t]{3}{*}{0.001} \\
\hline & Patients & $0.9 \%$ & $56.6 \%$ & $39.8 \%$ & \\
\hline & Total & $0.8 \%$ & $69.9 \%$ & $27.7 \%$ & \\
\hline \multirow{3}{*}{$\begin{array}{l}\text { Spray deodorant should be applied as } \\
\text { intra-vaginally as possible }\end{array}$} & Nurses & $0.7 \%$ & $64.7 \%$ & $31.6 \%$ & \multirow[t]{3}{*}{0.141} \\
\hline & Patients & $0.0 \%$ & $52.2 \%$ & $45.1 \%$ & \\
\hline & Total & $0.4 \%$ & $59.0 \%$ & $37.8 \%$ & \\
\hline \multirow{3}{*}{$\begin{array}{l}\text { Vaginal douching is recommended whenever } \\
\text { there is a change in vaginal discharge }\end{array}$} & Nurses & $32.4 \%$ & $27.9 \%$ & $36.8 \%$ & \multirow[t]{3}{*}{0.003} \\
\hline & Patients & $12.4 \%$ & $36.3 \%$ & $47.8 \%$ & \\
\hline & Total & $23.3 \%$ & $31.7 \%$ & $41.8 \%$ & \\
\hline \multirow{3}{*}{$\begin{array}{l}\text { Vaginal douching is recommended after each } \\
\text { sexual intercourse }\end{array}$} & Nurses & $36.8 \%$ & $40.4 \%$ & $22.1 \%$ & \multirow[t]{3}{*}{0.0001} \\
\hline & Patients & $15.0 \%$ & $41.6 \%$ & $40.7 \%$ & \\
\hline & Total & $26.9 \%$ & $41.0 \%$ & $30.5 \%$ & \\
\hline \multirow{3}{*}{$\begin{array}{l}\text { Vaginal douching is recommended after } \\
\text { menstruation }\end{array}$} & Nurses & $27.9 \%$ & $47.1 \%$ & $21.3 \%$ & \multirow[t]{3}{*}{0.001} \\
\hline & Patients & $13.4 \%$ & $39.3 \%$ & $43.8 \%$ & \\
\hline & Total & $21.4 \%$ & $43.5 \%$ & $31.5 \%$ & \\
\hline \multirow[t]{3}{*}{ Vaginal douching can hurt the vaginal mucosa } & Nurses & $52.2 \%$ & $12.5 \%$ & $33.1 \%$ & \multirow[t]{3}{*}{0.004} \\
\hline & Patients & $29.2 \%$ & $18.6 \%$ & $49.6 \%$ & \\
\hline & Total & $41.8 \%$ & $15.3 \%$ & $40.6 \%$ & \\
\hline \multirow{3}{*}{$\begin{array}{l}\text { Vaginal douching should not be done } \\
\text { unless recommended by a doctor }\end{array}$} & Nurses & $63.2 \%$ & $18.4 \%$ & $16.2 \%$ & \multirow[t]{3}{*}{0.0001} \\
\hline & Patients & $30.1 \%$ & $18.6 \%$ & $48.7 \%$ & \\
\hline & Total & $48.2 \%$ & $18.5 \%$ & $30.9 \%$ & \\
\hline \multirow[t]{3}{*}{ Vaginal douching causes a cystocele } & Nurses & $2.9 \%$ & $36.0 \%$ & $59.6 \%$ & \multirow[t]{3}{*}{0.036} \\
\hline & Patients & $1.8 \%$ & $20.4 \%$ & $73.5 \%$ & \\
\hline & Total & $2.4 \%$ & $28.9 \%$ & $65.9 \%$ & \\
\hline \multirow{3}{*}{$\begin{array}{l}\text { Regular application of antiseptics prevents } \\
\text { vaginal infections }\end{array}$} & Nurses & $21.3 \%$ & $56.6 \%$ & $19.1 \%$ & \multirow[t]{3}{*}{0.223} \\
\hline & Patients & $16.8 \%$ & $50.4 \%$ & $30.1 \%$ & \\
\hline & Total & $19.3 \%$ & $53.8 \%$ & $24.1 \%$ & \\
\hline \multirow[t]{3}{*}{ Cotton underwear prevent vaginal infections } & Nurses & $65.2 \%$ & $24.4 \%$ & $9.6 \%$ & \multirow[t]{3}{*}{0.143} \\
\hline & Patients & $70.8 \%$ & $15.0 \%$ & $10.6 \%$ & \\
\hline & Total & $67.7 \%$ & $20.2 \%$ & $10.1 \%$ & \\
\hline \multirow{3}{*}{$\begin{array}{l}\text { Regular vaginal douching prevents vaginal } \\
\text { infections }\end{array}$} & Nurses & $34.6 \%$ & $41.2 \%$ & $23.5 \%$ & \multirow[t]{3}{*}{0.007} \\
\hline & Patients & $18.6 \%$ & $39.8 \%$ & $38.9 \%$ & \\
\hline & Total & $27.3 \%$ & $40.6 \%$ & $30.5 \%$ & \\
\hline Tight-fitting clothes prevent vaginal infections & Nurses & $6.6 \%$ & $77.9 \%$ & $14.0 \%$ & 0.136 \\
\hline & Patients & $10.6 \%$ & $65.5 \%$ & $19.5 \%$ & \\
\hline & Total & $8.4 \%$ & $72.3 \%$ & $16.5 \%$ & \\
\hline Wiping after miction/defecation must be done & Nurses & $93.4 \%$ & $1.5 \%$ & $4.4 \%$ & 0.0003 \\
\hline & Patients & $77.0 \%$ & $4.4 \%$ & $14.2 \%$ & \\
\hline & Total & $85.9 \%$ & $2.8 \%$ & $8.8 \%$ & \\
\hline Vaginal sprays eradicate bacteria responsible for vaginitis & Nurses & $3.7 \%$ & $56.6 \%$ & $39.0 \%$ & 0.0001 \\
\hline
\end{tabular}


Table 3 Extent of knowledge regarding reproductive health issues in females patients and nurses (Continued)

\begin{tabular}{|c|c|c|c|c|c|}
\hline & Patients & $15.0 \%$ & $29.2 \%$ & $53.1 \%$ & \\
\hline & Total & $8.8 \%$ & $44.2 \%$ & $45.5 \%$ & \\
\hline \multirow[t]{3}{*}{ Sprays are strictly harmless products } & Nurses & $2.9 \%$ & $55.9 \%$ & $40.4 \%$ & \multirow[t]{3}{*}{0.646} \\
\hline & Patients & $3.5 \%$ & $52.2 \%$ & $41.6 \%$ & \\
\hline & Total & $3.2 \%$ & $54.2 \%$ & $41.0 \%$ & \\
\hline \multirow{3}{*}{$\begin{array}{l}\text { Allergic or irritative reactions to deodorants may occur even } \\
\text { if their previous use did not cause any problem }\end{array}$} & Nurses & $56.6 \%$ & $14.0 \%$ & $26.5 \%$ & \multirow[t]{3}{*}{0.0001} \\
\hline & Patients & $28.3 \%$ & $18.6 \%$ & $50.4 \%$ & \\
\hline & Total & $43.8 \%$ & $16.1 \%$ & $37.3 \%$ & \\
\hline \multirow{3}{*}{$\begin{array}{l}\text { Allergic or irritative reactions to deodorants do not require } \\
\text { medical follow-up }\end{array}$} & Nurses & $5.1 \%$ & $79.4 \%$ & $14.7 \%$ & \multirow[t]{3}{*}{0.0001} \\
\hline & Patients & $6.2 \%$ & $45.1 \%$ & $46.0 \%$ & \\
\hline & Total & $5.6 \%$ & $63.9 \%$ & $28.9 \%$ & \\
\hline \multirow{3}{*}{$\begin{array}{l}\text { Modification of the quantity of vaginal discharge without signs } \\
\text { of infection does not occur in healthy women }\end{array}$} & Nurses & $30.9 \%$ & $55.1 \%$ & $13.2 \%$ & \multirow[t]{3}{*}{0.002} \\
\hline & Patients & $22.1 \%$ & $43.4 \%$ & $31.9 \%$ & \\
\hline & Total & $26.9 \%$ & $49.8 \%$ & $21.7 \%$ & \\
\hline \multirow{3}{*}{$\begin{array}{l}\text { Persistent white to yellow vaginal discharge in small } \\
\text { quantities is normal }\end{array}$} & Nurses & $69.1 \%$ & $17.6 \%$ & $11.8 \%$ & \multirow[t]{3}{*}{0.001} \\
\hline & Patients & $46.0 \%$ & $22.1 \%$ & $28.3 \%$ & \\
\hline & Total & $58.6 \%$ & $19.7 \%$ & $19.3 \%$ & \\
\hline \multirow{3}{*}{$\begin{array}{l}\text { Tampons should be changed twice daily regardless of the } \\
\text { blood flow, to prevent blocking of normal vaginal discharge }\end{array}$} & Nurses & $40.4 \%$ & $22.8 \%$ & $35.3 \%$ & \multirow[t]{3}{*}{0.0001} \\
\hline & Patients & $20.4 \%$ & $15.9 \%$ & $60.2 \%$ & \\
\hline & Total & $31.3 \%$ & $19.7 \%$ & $46.6 \%$ & \\
\hline \multirow{3}{*}{$\begin{array}{l}\text { A genital infection in the partner is not considered a source } \\
\text { of vaginal infection }\end{array}$} & Nurses & $8.8 \%$ & $80.9 \%$ & $9.6 \%$ & \multirow[t]{3}{*}{0.119} \\
\hline & Patients & $10.6 \%$ & $69.0 \%$ & $17.7 \%$ & \\
\hline & Total & $9.6 \%$ & $75.5 \%$ & $13.3 \%$ & \\
\hline
\end{tabular}

infections (STI). Twenty-seven percent of the 295 recruited adolescent women used feminine wipes and this was related to a recent STD [15]. Feminine wipe use may irritate the vulvar skin and predispose to vulvar dermatitis. Our results show a widespread use of wipes among patients which could be due to lack of information. A small percentage of patients (4.4\%) and nurses (1.5\%) reported using intimate deodorant sprays, which is less than the $29 \%$ reported by Ott et al.[15] probably due to the lack of publicity about these products in our country. In addition, there is an obvious lack of information mainly among patients regarding the potential harm resulting from their use (vulvar dermatitis, allergic reactions...) [16].

Women often erroneously perceive their personal practices as safe since they become used to it. Marin et al. reported that over $60 \%$ of 530 women attending a specialty clinic for vulvar diseases, reported adverse intimate hygiene practices which is somehow similar to the results we obtained [17]. Education about adequate feminine hygiene practices is therefore crucial to improve Lebanese women's reproductive health, Nurses play a crucial role in promoting reproductive health by correcting false information about feminine hygiene.
One of the limitations of our study is the selection bias, the majority of women being married, Christian and of higher education level. However, one would argue that the lack of awareness about adequate practices demonstrated among educated women would also be present among less-educated women. Being an observational study represents a limitation to attain solid conclusions. It would be useful to perform a similar crosssectional study on a sample of women admitted to hospitals all over Lebanon, and to compare the results obtained before and after educational campaigns, personal hygiene classes or other informative interventions. Our study represents a pilot study in Lebanon and could lead to metaanalyses or larger comparative studies that would enrich our knowledge of feminine hygiene.

\section{Conclusion}

Lack of information about adequate feminine hygiene practices is common among Lebanese women. Nurses seem to have more appropriate practice and knowledge about this issue than patients. Education provided by health care providers is important to optimize reproductive health in Lebanon. 


\section{Authors' contributions}

AK and SM designed the study and were involved in writing of the draft; SM and EA were responsible for project conception and development; PA and GA were responsible for data collection and statistics. DR and PA participated in coordinating the different steps and execution of the study. All authors read and approved the final manuscript.

\section{Competing interests}

Authors report no funding for this study. Authors don't have any competing interests. Hospital's ethical committee approved this study.

\section{Author details}

Obstetrics and Gynecology Department, Faculty of Medicine, Saint Joseph University, Hotel-Dieu de France Hospital, PO Box: 166830Adib Ishac Street, Achrafie, Beirut, Lebanon. ${ }^{2}$ Faculty of Medicine, Saint Joseph University, Beirut, Lebanon.

Received: 15 June 2015 Accepted: 10 May 2016

Published online: 23 May 2016

\section{References}

1. Wilson C. Recurrent vulvovaginitis candidiasis; an overview of traditional and alternative therapies. Adv Nurse Pract. 2005;13(5):24-9. quiz 30.

2. Foxman B, Marsh JV, Gillespie B, Sobel JD. Frequency and response to vaginal symptoms among white and African American women: results of a random digit dialing survey. J Womens Health Off Publ Soc Adv Womens Health Res. 1998;7(9):1167-74.

3. Anderson MR, Klink K, Cohrssen A. Evaluation of vaginal complaints. JAMA. 2004;291(11):1368-79.

4. Brotman RM, Klebanoff MA, Nansel TR, Andrews WW, Schwebke JR, Zhang J, et al. A longitudinal study of vaginal douching and bacterial vaginosis-a marginal structural modeling analysis. Am J Epidemiol. 2008;168(2):188-96.

5. Shaaban OM, Youssef AEA, Khodry MM, Mostafa SA. Vaginal douching by women with vulvovaginitis and relation to reproductive health hazards. BMC Womens Health. 2013;13:23.

6. Erbil N, Alışarlı A, Terzi HÇ, Özdemir K, Kuş Y. Vaginal douching practices among Turkish married women. Gynecol Obstet Invest. 2012;73(2):152-7.

7. Ege $E$, Timur S, Zincir H, Egri M, Sunar Reeder B. Women's douching practices and related attitudes in eastern Turkey. J Obstet Gynaecol Res. 2007;33(3):353-9.

8. Aral $\mathrm{SO}$, Mosher WD, Cates W. Vaginal douching among women of reproductive age in the United States: 1988. Am J Public Health. 1992;82(2):210-4.

9. Cottrell $\mathrm{BH}$. Vaginal douching practices of women in eight Florida panhandle counties. J Obstet Gynecol Neonatal Nurs JOGNN NAACOG. 2006;35(1):24-33.

10. Grimley DM, Annang L, Foushee HR, Bruce FC, Kendrick JS. Vaginal douches and other feminine hygiene products: women's practices and perceptions of product safety. Matern Child Health J. 2006:10(3):303-10.

11. Carter M, Gallo M, Anderson C, Snead MC, Wiener J, Bailey A, et al. Intravaginal cleansing among women attending a sexually transmitted infection clinic in Kingston, Jamaica. West Indian Med J. 2013;62(1):56-61.

12. Ekpenyong CE, Etukumana EA. Ethnicity, family socioeconomic inequalities, and prevalence of vaginal douching among college students: the implication for health. J Am Coll Health. 2013;61(4):222-30.

13. Cottrell $\mathrm{BH}$. An updated review of of evidence to discourage douching: MCN. Am J Matern Nurs. 2010;35(2):102-7.

14. Zhang J, Hatch M, Zhang D, Shulman J, Harville E, Thomas AG. Frequency of douching and risk of bacterial vaginosis in African-American women. Obstet Gynecol. 2004;104(4):756-60.

15. Ott MA, Ofner S, Fortenberry JD. Beyond douching: use of feminine hygiene products and STI risk among young women. J Sex Med. 2009;6(5):1335-40.

16. Gowdy JM. Feminine deodorant sprays. N Engl J Med. 1972;287(4):203.

17. Marin MG, King R, Sfameni S, Dennerstein GJ. Adverse behavioral and sexual factors in chronic vulvar disease. Am J Obstet Gynecol. 2000;183(1):34-8.

\section{Submit your next manuscript to BioMed Central and we will help you at every step:}

- We accept pre-submission inquiries

- Our selector tool helps you to find the most relevant journal

- We provide round the clock customer support

- Convenient online submission

- Thorough peer review

- Inclusion in PubMed and all major indexing services

- Maximum visibility for your research

Submit your manuscript at www.biomedcentral.com/submit 